Article

\title{
How Do Stakeholders Perceive Barriers to Large-Scale Wind Power Diffusion? A Q-Method Case Study from Ceará State, Brazil
}

\author{
Cláudio Albuquerque Frate ${ }^{1,2, *(1)}$ and Christian Brannstrom ${ }^{2,3}$ (D) \\ 1 Center for Sustainable Development, University of Brasília, Brasília DF 72405-610, Brazil \\ 2 Department of Geography, Federal University of Ceará, Fortaleza CE 60455-900, Brazil; \\ cbrannst@geos.tamu.edu \\ 3 Department of Geography, Texas A\&M University, College Station, TX 77843, USA \\ * Correspondence: claudiofrate@unb.br; Tel.: +55-61-3307-5664
}

Received: 23 April 2019; Accepted: 28 May 2019; Published: 30 May 2019

\begin{abstract}
High penetration of renewable power requires technical, organizational, and political changes. We use Q-method, a qualitative-quantitative technique, to identify and analyze views held by key actors on challenges for large-scale diffusion of wind power in Ceará State, Brazil, an early leader in wind power with $2.05 \mathrm{GW}$ installed capacity. Four quantitatively determined social perspectives were identified with regard to views on challenges for wind power expansion: (1) failing because of the grid; (2) environmental challenges; (3) planning for wind, and (4) participating in wind. Each social perspective emphasizes a different array of barriers, such as cost of new transmission lines, transformation of a hydro-thermal mental model, predictive capacity for wind energy, and the need for participatory forum. Understanding the subjective views of stakeholders is a key first step in eventually reducing these barriers to renewable power penetration through diverse policy interventions.
\end{abstract}

Keywords: wind power; barriers; Q-method; Brazil

\section{Introduction}

Governments and investors have made considerable efforts to increase penetration of renewable power, but uptake is low compared to potential [1,2]. Technical, organizational, market, environmental, and social factors are barriers to renewable power penetration [3]. Institutional barriers to renewable power penetration include statutory-regulatory frameworks and "norms, values, cognitive frameworks, and regulations" [4] (p. 151). The technical-institutional paradigm change in the traditional power sector is considered important because renewable energy technologies demand structural, social, organizational, and economic changes [5-8]. Observers have reported "strong resistance to change firm behavior regarding penetration in the electricity sector" [9] (p. 12236) and have claimed that "pre-existing infrastructure, both physical and institutional," impedes adoption of new power generation technologies [10] (p. 1499). Here we ask stakeholders in one region about barriers to wind-power diffusion using the qualitative-quantitative Q-method as a means of empirically determining subjective views.

Our study of barriers to wind power is focused on Brazil, where the electricity portfolio in 2018 was composed of hydroelectricity $(60 \%)$, thermal (natural gas, coal, biomass, diesel, and nuclear; $27 \%$ ), wind (8\%), imported power (4\%), and solar photovoltaic (1\%) [11]. Severe droughts from 2011 to 2015 sharply decreased hydroelectricity generation and increased electricity prices, pushing planners and government officials to support wind power development. Since 2002 the Brazilian government has expanded and diversified its energy portfolio focusing on public policies for auctions, credit, research, 
imports, and licensing [12-14]. According to Brazilian energy planners, wind power in Brazil will increase to $27 \mathrm{GW}$ (12.3\%) in 2027, likely exceeding biomass and small hydro power [11].

Previous work identified barriers to wind power expansion by the number of mentions during qualitative interviews [15], but here we apply different analytical techniques and expand the type of stakeholder interviewed by including state and federal regulators and electrical system operators. We determine statistically significant views held among stakeholders (planners, regulators, grid managers, power distributors, wind turbine manufacturers, industrialists, and entrepreneurs) in the power sector regarding techno-organizational challenges for large scale wind power diffusion in the state of Ceará. Identifying social perspectives, or clusters of opinions, on obstacles to wind-power expansion through a qualitative-quantitative procedure shows specific ways of viewing particular challenges that are rooted in certain sectors and groups of the electrical power industry. Our findings contribute to understanding barriers as expressed for Ceará state, thus showing how barriers recognized globally may be defined, prioritized, or understood differently according to particular institutional and regional constraints and opportunities. Views are heterogeneous and situated, rather than homogenous and generalized, not always mapping onto organizations or groups with a stake in wind power. Knowledge of the complex nature of stakeholder views may help develop strategies for more favorable techno-institutional policies for wind power in Northeastern Brazilians' electrical subsystem.

\section{Materials and Methods}

\subsection{Study Region}

Significant Brazilian wind resources are located in coastal areas and interior uplands of Brazil's semi-arid northeastern region [16,17]. For example, installed capacity in Rio Grande do Norte (3.98 GW), Bahia (3.55 GW), and Ceará (2.05 GW) states provide more than half of Brazil's total installed wind capacity as of February 2019 [18]. The semi-arid northeastern region historically has received most power from hydroelectric dams, but increasing recurrence and severity of drought in the past several years has required power production from thermal and wind sources [19-21]. In 2016, wind power supplied around $30 \%$ of the northeastern region's electricity [12].

We carried out this study in Ceará state, which offers high potential for wind power owing to its diurnal coastline and countryside wind power profile that correlates with the Northeast's load curve [22]. Approximately $68 \%$ of Ceará's installed capacity is located within $5 \mathrm{~km}$ of the shoreline [23], the result of favorable geopolitical conditions, strong wind energy potential, large expanses of semiarid land, and a long legacy of severe drought [24].

\subsection{Study Design}

We deployed Q-method to determine subjective views of diverse stakeholders in Ceará's wind power sector. Q-method is a qualitative-quantitative approach to subjectivity that has been used to analyze diverse energy policy issues [25-29]. Limitations of $Q$ method, especially the inability to generalize, are well established in the literature; in this study, our main challenge was gaining access to busy, highly skilled, and well-educated representatives in the electricity sector. After we obtained access to these respondents, Q-method was easily understood and helped dispel any lingering mistrust regarding the motivations of the research. Confidentiality was guaranteed by the first author to the respondents, who understood that the sorts would be analyzed statistically.

We followed well-established procedures. First, we created a concourse of statements from 19 semi-structured interviews with three representatives of wind turbine producers, three wind energy entrepreneurs, two grid managers, three electricity utility representatives, four regulators, and four governmental planners. Interviews were purposive, following Q-method protocols and our knowledge of Brazil's electricity sector, which is dominated by state-run firms and private firms that bid on electricity supply auctions. Unlike a recent study of stakeholder views [15], we included respondents with knowledge of the Northeast Electrical Subsystem, one of five subsystems of Brazil's National 
Interconnected Electric System (SIN); the role of the National Electric System Operator (ONS) over coordination and control of its power plants and transmission lines; and the planning and regulatory functions of the federal Energy Research Company (EPE, Rio de Janeiro, Brazil) and National Electric Energy Agency (ANEEL).

Interviews were carried out between 22 July 2015 and 29 July 2016 in Brasília, Belo Horizonte, Rio de Janeiro, and Fortaleza (state capital of Ceará). Interviews lasted between 30 and $60 \mathrm{~min}$ each. The guiding question for interviews was: "Which are the main technical and organizational challenges to the large-scale expansion of wind energy technology in the Ceará?" After reaching research saturation, we coded interview transcripts and identified 167 statements on the basis of balance among respondents and aiming to achieve a wide spectrum of views. Four social scientists knowledgeable about wind-energy technology issues, energy, and the environmental policies of the region, scored these statements for suitability for this study using relevance, frequency, and similarities as criteria. This scoring process produced a rank list of 26 statements for the Q-set grouped into categories emerging from the data.

The second phase included purposive selection of 21 well trained and experienced professionals in Northeastern Brazil's electricity sector and wind power technology. (The initial 19 respondents were included in the 21 professionals.) We asked wind energy entrepreneurs, wind turbine manufactures, grid managers, electricity transmission utilities, regulators, industrialists (representatives of Ceará's industrial sector who could manufacture items for wind-power), and planners to sort the statements into a quasi-normal distribution between 28 November 2016 and 14 March 2017. Respondents ranked the statements in a semi-normal distribution that forced them to place the statements into a grid that allowed for only one statement corresponding to "most agree with my views" $(+4)$ and only one for the "most disagree with my views" (-4), while six statements were permitted in the "neutral" category (Table 1). The first author was present during the sorting and discussed the procedure with each respondent, who was encouraged to rank the statements according to his or her professional opinion. We are confident that respondents understood the procedures and produced reliable results. Each sort was followed by an interview focusing on rationale, lasting approximately $60 \mathrm{~min}$.

Table 1. Q-sort distribution for 26 statements.

\begin{tabular}{cccccccccc}
\hline & \multicolumn{3}{c}{ Most Disagree } & \multicolumn{3}{c}{ Neutral } & \multicolumn{3}{c}{ Most Agree } \\
\hline Value & -4 & -3 & -2 & -1 & 0 & 1 & 2 & 3 & 4 \\
Frequency & 1 & 2 & 3 & 4 & 6 & 4 & 3 & 2 & 1 \\
\hline
\end{tabular}

The third phase of Q-method involved the correlation and factor analysis using dedicated freeware [30] to determine the correlation matrix, extract and rotate (through VARIMAX rotation built into the freeware) significant factors, and calculate statement z-scores for each factor. We selected a four-factor solution that accounted for $56 \%$ of variance (Tables 2 and 3). We conducted preliminary analysis of a five-factor solution, but it explained little additional variance and increased error; similar preliminary work concluded that a three-factor solution explained too little variance and provided unclear factors. We relied on "simplicity, clarity, distinction, and stability" in our final selection of four factors [31] (p. 31). Finally, we labeled the social perspectives according to the ideas conveyed in the statistically significant defining statements and the rationale provided by respondents after sorting the 26 statements. 
Table 2. Factor characteristics.

\begin{tabular}{ccccc}
\hline & Factor $\mathbf{1}$ & Factor $\mathbf{2}$ & Factor 3 & Factor 4 \\
\hline Eigenvalue & 5.03 & 2.48 & 2.13 & 2.01 \\
No. of defining variables (sorts) & 4 & 5 & 5 & 3 \\
\% variance explained & 16 & 15 & 14 & 11 \\
Average relative coefficient & 0.8 & 0.8 & 0.8 & 0.8 \\
Composite reliability & 0.941 & 0.952 & 0.952 & 0.923 \\
Standard error of factor scores & 0.243 & 0.218 & 0.218 & 0.277 \\
Distinguishing statements & 9 & 8 & 7 & 6 \\
\hline
\end{tabular}

Table 3. Correlations between factor scores with $98 \%$ confidence interval [32] (p. 286).

\begin{tabular}{ccccc}
\hline Factor & $\mathbf{1}$ & $\mathbf{2}$ & $\mathbf{3}$ & $\mathbf{4}$ \\
\hline 1 & 1 & $0.1332 \pm 0.193$ & $0.2469 \pm 0.184$ & $0.1601 \pm 0.191$ \\
2 & & 1 & $0.2493 \pm 0.184$ & $0.1071 \pm 0.194$ \\
3 & & & 1 & $0.1049 \pm 0.194$ \\
4 & & & & 1 \\
\hline
\end{tabular}

The fourth step of Q-method is to interpret factors, sometimes accompanied by a validation phase with "loaders" on factors (Table 4). We refer to statements by number and respondents by number below. In Q-method, distinguishing statements represent statistically significant differences between the ranking in one factor compared to all other factors at $p<0.01$ or $p<0.05$. Factors are considered social perspectives in that they are communicated between and among people.

Table 4. Rotated factor loadings ( ${ }^{*}$ indicates defining sort) with respondent type summarized.

\begin{tabular}{cccccc}
\hline \multirow{2}{*}{ Respondent No. } & Respondent Sector & \multicolumn{3}{c}{ FACTOR } \\
\cline { 3 - 6 } & & $\mathbf{1}$ & $\mathbf{2}$ & $\mathbf{3}$ & $\mathbf{4}$ \\
\hline 1 & Wind power firm & 0.4733 & 0.0906 & 0.4983 & -0.2587 \\
2 & Wind power firm & -0.0616 & -0.0085 & 0.114 & $0.7740^{*}$ \\
3 & Wind power firm & 0.1708 & 0.1548 & 0.0069 & $0.7364^{*}$ \\
4 & Wind power firm & 0.5243 & $0.6639 *$ & 0.2076 & -0.0329 \\
5 & Transmission & -0.1061 & $0.7522 *$ & 0.0332 & 0.1531 \\
6 & Transmission & $0.7877^{*}$ & -0.1647 & 0.145 & 0.1436 \\
7 & Transmission & 0.121 & 0.5291 & 0.5565 & 0.294 \\
8 & Energy regulator & 0.5054 & 0.4539 & 0.3517 & 0.0713 \\
9 & Energy regulator & 0.0062 & -0.124 & $0.5626^{*}$ & -0.0186 \\
10 & Energy regulator & -0.4475 & 0.3114 & $0.6557 *$ & 0.1532 \\
11 & Energy regulator & 0.1545 & 0.1573 & $0.7024 *$ & 0.3007 \\
12 & Energy planner & 0.259 & 0.0333 & $0.6226^{*}$ & -0.1211 \\
13 & Energy planner & 0.5033 & $0.6076 *$ & -0.0491 & -0.2161 \\
14 & Grid operator & $0.5863 *$ & -0.0345 & 0.177 & 0.0201 \\
15 & Grid operator & 0.387 & 0.0186 & $0.6091 *$ & 0.0984 \\
16 & Grid operator & 0.0825 & -0.0364 & 0.1381 & 0.3199 \\
17 & Industrialist & -0.1353 & $0.8048 *$ & 0.1697 & -0.0952 \\
18 & Industrialist & $0.5213 *$ & 0.3644 & -0.1408 & 0.059 \\
19 & Manufacturer & 0.0049 & $0.4757 *$ & -0.1034 & 0.1467 \\
20 & Manufacturer & 0.0294 & 0.2149 & -0.3633 & $0.6768^{*}$ \\
21 & Manufacturer & $0.7209 *$ & 0.0125 & 0.1615 & 0.3044 \\
\hline
\end{tabular}

\section{Results}

We identified four social perspectives (factors) relating to wind power challenges expansion in Northeast Brazil (Appendix A): (1) failing because of the grid; (2) environmental challenges; (3) planning for wind, and (4) participating in wind. These social perspectives are comprised of statistically significant defining statements. Below we describe these results in detail. 


\subsection{Failing Because of the Grid (Factor 1)}

The "Failing because of the grid" social perspective is defined by respondents who represent power distribution, industrialists, grid managers, and manufacturers who were concerned about issues closest to their expertise, including costs of future transmission lines affecting auction prices, low short-circuit capacity, and lack of resources of the grid operator. This social perspective embodies analysis of large-scale wind-power diffusion in Northeastern Brazil that emphasized the need for upgrades to transmission infrastructure "to allow for interstate balancing in order to avoid curtailment of excess wind energy" [22] (p. 413). The Northeast Electrical Subsystem has a low short-circuit capacity and a poor electric grid in rural areas. The Northeast electrical subsystem spinning reserve capacity is large, although debate exists on its precise size relative to the electrical generation system [12,21,33].

Additional concerns about the electrical transmission grid are voiced through ranking of statements predicting bottlenecks of construction costs of future transmission lines are included in the costs of the wind energy auctions (Statement 12; $p<0.01, \mathrm{Z}=2.00$ ) and the urgent need for the SIN to resolve the short-circuit capacity problem to permit increased penetration of wind power (Statement 19; $p<0.01$, $Z=1.30$ ). Indeed, respondents referenced the perceived small short-circuit capacity in justifying their rankings. For example, an industrialist who loaded on this factor argue that "when considered regionally, you can see that the wind energy demand curve is becoming flatter in relation to demand, which reduces the importance of short-circuit capacity" (Respondent 18; Loading $=0.5213$ ). A power distributor said, "A small short-circuit capability will require [for the proper functioning of the wind turbine control part] synchronous compensators that will increase cost and will not definitively solve the grid problem" (Respondent 6; Loading $=0.7877$ ). Notably, concern with short-circuit capacity existed with "Participating in wind" (Factor 4), which ranked statement 19 even higher $(Z=2.54)$, indicating greater concern for short-circuit capacity as a bottleneck for wind power expansion.

"Failing because of the grid" strongly rejected a statement claiming that the National System Operator (ONS; Operador Nacional do Sistema) currently has necessary resources to dispatch and manage operations of the SIN (Statement 23; $p<0.05, \mathrm{Z}=-1.26$ ). For example, a power distributor (Respondent 6; Loading $=0.7877$ ) argued that the ONS "is not well prepared in terms of tools and regulations for a scenario of high penetration of wind power," given its intermittent nature and necessary spinning reserve. An energy planner added that the ONS is "working on it but has to get better in its mathematical models" (Respondent 13; Loading $=0.5033$ ). Notably, respondents loading on other factors held opposing views on the ONS. For example, entrepreneurs with detailed knowledge of the technical staff of the ONS for the Northeastern System described them as "a leading-edge group, recognized globally" (Respondent 2) and "they [technical staff] learned over time" (Respondent 3; Loading $=0.0069$ ). A power distributor indicated that "in the beginning" there was concern about the ONS (Respondent 7; Loading $=0.5565$ ) and a regulator noted that the ONS has "very strong technical capacity to make wind forecasts" (Respondent 10; Loading $=0.6557$ ).

Several respondents who loaded on other factors disagreed with the negative assessment of the grid presented in "Failing because of the grid." Belief in technological progress was a key theme, such as in the case of a respondent who argued that "the short-circuit capacity problem is easily resolved through synchronous compensators" (Respondent 12), while another respondent agreed, arguing that short-circuit capacity "is easily resolved because it depends on connection points and these studies are being done daily" (Respondent 11). Other respondents argued that "advances in wind turbine technology, with the help of capacitor banks increase system inertia" (Respondent 7) and put faith in institutional reforms to reduce the short-circuit problem (Respondent 10).

"Failing because of the grid" prioritizes the grid and the operator as main obstacles, so it is understandable that this social perspective lowers the importance of other possible barriers, such as opposition to wind power by environmental movements, lack of a regional forum for policy discussions, lack of national production chain, and the development of coal-fired power plants. For example, this factor disagrees with the statement indicating that easing environmental impact reporting would reduce a barrier for wind farms (Statement 22; $p<0.01, Z=-1.01$ ). As an entrepreneur said: "I think 
this would be a disaster. We need to return to the earlier licensing model," referring to a simplified licensing procedure (Respondent 1 ; Loading $=0.4733$ ).

\subsection{Environmental Challenges (Factor 2)}

The "Environmental challenges" social perspective believes that the hydropower mentality and environmental challenges are potential obstacles to wind power penetration. Other possible obstacles, such as regulatory specialists, national production chain, and a regional policy forum, have reduced importance as barriers. Entrepreneurs, power distributors, planners, industrialists and wind turbine manufacturers loaded on this factor.

"Environmental challenges" is concerned with the environmental movement's opposition and its capacity to block licensing new wind farms (Statement 21; $p<0.05, Z=1.39$ ). A federal planner (Respondent 12; Loading $=0.6076$ ) affirmed that "constructing wind farms on mobile and fixed dunes, and the destruction of lakes, mangroves, and estuaries initiated a movement in Ceará opposed to wind power." This view is compatible with studies offering criticisms of how local elites influence the licensing process $[24,34]$. For comparison, respondents who loaded on other factors minimized environmental opposition, arguing that "there is no environmental opposition to wind farm licensing" (Respondent 6) and "no strong environmental movement" in Ceará, suggesting disingenuous motivations of environmental opponents for "financial bargaining" rather than genuine opposition (Respondent 11).

Another defining characteristic of "Environmental challenges" is the need to "transform the mental model of the technical staff of the institutions of electric sector" away from hydrothermal power (Statement 16; $p<0.01, \mathrm{Z}=0.97$ ). We accepted "mental model," in the words of respondents, as the idea that a mentality regarding the optimal functioning of the electrical system-rooted in hydropower-has existed among regulators and utility operators since the origins of the Brazilian electrical system. This model is an environmental challenge because it favors continued reliance on hydropower and increased thermal power, both of which are frequently opposed by environmental groups interested in promoting wind and solar power generation. One industrial sector respondent argued that "planning has not evolved to accommodate wind power" in the new hydro-thermal-wind generation matrix (Respondent 17; Loading $=0.8048)$. Another representative of the electrical sector argued that the planning "still thinks in terms of hydro and thermal power, and it needs to modernize to accommodate wind power expansion" (Respondent 18; Loading $=0.3644$ ). An entrepreneur agreed, describing the "mentality of the electrical sector" as that of "barrageiros" or "dam-builders," a colloquial term used to describe workers and professionals specialized in building dams for hydropower (Respondent 3; Loading $=0.1548$ ). A planner (Respondent 13; Loading $=0.6076$ ) argued that wind power technology is poorly understood by technical staff of hydro-thermal generators.

Unlike "Failing because of the grid," regulatory specialists for wind technologies were competent (Statement $1 ; p<0.01, \mathrm{Z}=-1.43$ ). For example, a respondent argued that ANEEL has "well-trained professionals capable of competent regulation" (Respondent 12; Loading $=0.6226$ ). An industry representative commented on the "competent specialists" who worked for national and local regulatory agencies, while suggesting that they could do more to "prioritize wind power expansion" (Respondent 18 ; Loading $=0.3644)$. No barriers were observed in terms of a regional forum to resolve bottlenecks for the wind energy expansion (Statement $4 ; p<0.01, \mathrm{Z}=-2.01$ ) or lack of national production chain for wind power (Statement 2; $p<0.05, Z=-1.50$ ).

\subsection{Planning for Wind (Factor 3)}

The "Planning for wind" social perspective is defined by the claims that wind farms must improve site analysis (Statement 13; $p<0.05, Z=2.08$ ), rely on better predictive capacity (Statement 9; $p<0.05$, $Z=1.16$ ), and avoid political decisions about the value-added tax (Statement $24 ; p<0.01, Z=-1.37$ ). Respondents representing regulators, planners and grid managers loaded on this factor.

For one entrepreneur, "site analyses provide the basis for profitable project without future surprises" (Respondent 1; Loading $=0.4983$ ) while a power distributor said that site analyses "considerably 
reduce delays in planning and construction" (Respondent 7; Loading $=0.5565$ ). Regarding predictive capacity, a regulator (Respondent, 10; Loading $=0.6557$ ) argued that accurate wind prediction was essential for improving short-term electricity markets while a grid distributor (Respondent 7; Loading $=0.5565$ ) claimed that wind prediction would help "achieve the dream of dispatchable wind power" and a planner affirmed the need to improve medium- and long-term predictions (Respondent, 12; Loading $=0.6363$ ).

Several respondents, who loaded on different factors, offered diverse views on the wind modeling problem as a bottleneck. For example, an entrepreneur (Respondent 3 ) emphasized the need to use "long-term historical data with local measurements" to "optimize dispatch, reduce spot prices, and facilitate adoption of wind technology to tropical conditions." Another entrepreneur (Respondent 2) agreed, stating that "we need mathematical models and a network of anemometers with real-time data." A power distributor (Respondent 6) commented that "low predictive accuracy for wind resources is compensated today by the huge spinning reserve, but that will not be enough in a future scenario of high wind penetration."

Views about tax revenue transfers in "Planning for wind" resonate with the technical and planning basis of this social perspective. Respondents wish to avoid involvement in directing the value-added tax (ICMS) to communities in municipalities that produce wind power. They doubted that municipal officials would transfer financial resources to communities affected by wind power (Respondent 3; Respondent 11, Loading $=0.7024$ ) and suggested that wealth transfers should be done by the state, not by wind power expansion (Respondent 12 ; Loading $=0.6226$ ). Similarly, a regulatory official argued that financial benefits of producing wind power should accrue more broadly, beyond a specific community, because the grid is interconnected (Respondent 8 ; Loading $=0.3517$ ). This finding suggests lack of trust by entrepreneurs regarding possible corruption of municipal officials who work with financial resources relating to wind power, in addition to reluctance among entrepreneurs to be responsible for providing financial benefits to municipalities from wind power generation, as there are other well established legal-financial avenues for municipalities to derive financial benefit from wind farms.

Differently from "Failing because of the grid," the "Planning for wind" perspective rejects the idea that the spinning reserve capacity in hydroelectric plants is a limiting factor of wind power expansion (Statement 10; $p<0.01, \mathrm{Z}=-1.89$ ). To justify his views, a grid distributor (Respondent 7 ; Loading $=0.5565$ ) compared Northeastern Brazil to Germany and Denmark, which have large installed capacity of wind power. Regulators argued that "some thermoelectric plants are appropriate to fill gaps in wind power" (Respondent, 10; Loading $=0.6557$ ). Brazil's "energy base will always be hydropower," according to another regulator, but that is not a barrier for wind power expansion, which is more contingent on "competitiveness" than spinning reserve (Respondent 11; Loading $=0.7024$ ).

\subsection{Participating in Wind (Factor 4)}

The "Participating in the wind" social perspective is comprised of entrepreneurs and wind turbine manufacturers concerned with lack of regional forum for operation and planning to reduce bottlenecks for wind energy expansion (Statement $4 ; p<0.01, \mathrm{Z}=1.41$ ). For example, an entrepreneur (Respondent 2; Loading $=0.7740$ ) pointed out that Brazil's northeastern region had "geographic and technical characteristics of available power sources that made dispatch and operation different from elsewhere in Brazil." Entrepreneurs argued that better integration and planning were present in the past because of regional forums (Respondent 3; Loading $=0.7364$ ) and that the former North and Northeast Coordination Committee (Comitê de Coordenação do Norte e Nordeste; CCON) helped inform national planners with relevant regional information (Respondent 2; Loading $=0.7740$ ).

One entrepreneur put the challenge in the following terms: "the 'coming together' is not happening. The bureaucracy cannot make decisions in their office using maps, but rather they must do it locally considering the diverse territories" (Respondent 3; Loading $=0.7364$ ). Similarly, a power distributor (Respondent 7; Loading $=0.2940)$ said that "each region had its power idiosyncrasies, which need to 
be heard at the federal level for successful wind power expansion." Notably, the need for regional planning groups is pronounced among entrepreneurs, rather than grid operators, suggesting a divide in how these stakeholder groups view barriers.

Additionally, "Participating in wind" rejects the idea that foreign labor and weak socio-technical modernization are obstacles to wind power expansion. The obstacle of short-circuit capacity (Statement 19) was ranked higher by this factor than "Failing because of the grid" (F1) and was summarized by an entrepreneur (Respondent 3; Loading = 0.7364): "short-circuit capacity, even with available wind, is a limiting factor because you can't distribute the electricity [without a good short-circuit capacity]." Another entrepreneur who loaded on this factor noted that "the legal understanding is that the national electrical system has the responsibility of distributing power generated by the firms because that is the basis for energy security" (Respondent 2; Loading $=0.7740$ ).

"Participating in wind" believes that a participatory and cooperative approach will benefit all stakeholders, and therefore disagreed with several possible challenges to wind-power penetration, such as temporal mismatch between the wind power implementation and the release of financing (Statement 6; $p<0.01 ; Z=-0.59$ ), the idea that use of foreign labor for installation, operation, and maintenance as an obstacle for wind power expansion (Statement 15; $p<0.01 ; \mathrm{Z}=-1.39$ ), and the claim that technical, human and organizational modernization of electric power concessionaires was necessary to facilitate wind energy expansion (Statement 18; $p<0.01 ; Z=-1.17$ ).

\section{Discussion}

Four social perspectives or clusters of opinion in Northeastern Brazil's wind power sector emphasize different barriers to wind expansion (Table 5). "Failing because of the grid" shows concern for the costs of future transmission lines and short-circuit capacity. This view displays concern about the ability of the grid operator to operate and dispatch in a hydro-thermo-wind setting and corroborates recent work indicating high concern with transmission and grid system as barriers [15]. "Environmental challenges" is more concerned with organizational issues, such as transformation of the hydro-thermal mental model of the technical staff of the electric sector and easing of environmental impact reporting. This view also believes that environmental opposition has capacity to block licensing of new wind farms while questioning the motivation of opposition groups. "Planning for wind" does not view spinning reserve capacity in hydroelectric plants as a limiting factor for wind energy expansion. At the same time, this perspective holds that strengthening of the predictive capacity of the wind energy resource could facilitate expansion. The view that predictive models need improvement suggests the importance of state investment into this key aspect of wind power integration into a national grid and resonates with reports of problems with wind forecasting [35]. "Planning for wind" has an electro-technical disagreement with "Failing because of the grid." The importance of site analysis for wind power expansion is highly relevant because it influences directly issues such as payback time, licensing procedures, auction prices, and investments. Political conditions are the main reasons why VAT (ICMS) should not be transferred via local governments to communities in the municipalities that produce energy.

The social perspectives differ significantly from each other in that they hold different barriers to be more important, indicating that barriers are perceived unevenly across key actors in the sector. Major differences between factors exist with regard to particular statements. Among the most salient is the technical capacity of ANEEL for wind power (Statement 1: Lack of regulatory specialists at the National Electricity Agency for wind technologies is a challenge) and short-circuit capacity (Statement 19: Short-circuit capacity of the national electric system must be solved for large-scale expansion). These divergent views exist for Statement 1 because some respondents may prioritize the quality of staff, while others may give importance to the number of staff. 
Table 5. Summary of four factors describing subjective views on barriers to wind power diffusion in northeastern Brazil.

\begin{tabular}{|c|c|c|c|c|}
\hline & $\begin{array}{l}\text { Failing Because of the } \\
\text { Grid (F1) }\end{array}$ & $\begin{array}{l}\text { Environmental } \\
\text { Challenges (F2) }\end{array}$ & $\begin{array}{l}\text { Planning for the } \\
\text { Wind (F3) }\end{array}$ & $\begin{array}{l}\text { Participating in Wind } \\
\text { (F4) }\end{array}$ \\
\hline Loader type(s) & $\begin{array}{l}\text { Power distributors, } \\
\text { industrialists, grid } \\
\text { managers, } \\
\text { manufacturers }\end{array}$ & $\begin{array}{c}\text { Entrepreneurs, power } \\
\text { distributors, planners, } \\
\text { industrialists, } \\
\text { manufacturers }\end{array}$ & $\begin{array}{l}\text { Regulators, planners, } \\
\text { grid managers }\end{array}$ & $\begin{array}{l}\text { Entrepreneurs, } \\
\text { industrialists }\end{array}$ \\
\hline $\begin{array}{l}\text { Key barrier(s) to wind } \\
\text { power expansion }\end{array}$ & $\begin{array}{l}\text { Costs of future } \\
\text { transmission lines } \\
\text { affect auction prices }\end{array}$ & $\begin{array}{l}\text { Easing environmental } \\
\text { impact reporting }\end{array}$ & Detailed site analysis & $\begin{array}{l}\text { Lack of regional forum } \\
\text { for operation and } \\
\text { planning }\end{array}$ \\
\hline Concerns & $\begin{array}{c}\text { Grid operator lacks } \\
\text { resources }\end{array}$ & Hydropower mentality & $\begin{array}{l}\text { Predictive capacity, } \\
\text { political decisions } \\
\text { about value-added tax }\end{array}$ & $\begin{array}{l}\text { Low short-circuit } \\
\text { capacity, lack of } \\
\text { regulators }\end{array}$ \\
\hline Rationale & $\begin{array}{l}\text { Fundamental grid } \\
\text { challenges }\end{array}$ & $\begin{array}{l}\text { Hydro-thermal mental } \\
\text { model not favorable to } \\
\quad \text { wind }\end{array}$ & $\begin{array}{l}\text { Prediction is essential } \\
\text { to dispatchable wind } \\
\text { power }\end{array}$ & $\begin{array}{l}\text { Northeastern Brazil } \\
\text { has distinct geographic } \\
\text { and technical } \\
\text { characteristics }\end{array}$ \\
\hline Consensus & \multicolumn{4}{|c|}{$\begin{array}{l}\text {-Turbines must be adjusted to temperature, salinity, and humidity characteristics } \\
\text {-Low concern for host community criticism and unrealized local employment expectations as causes } \\
\text { for reduced community acceptance }\end{array}$} \\
\hline
\end{tabular}

"Participating in wind" diverges from "Environmental challenges" in regard to the importance of a regional forum for decentralized electrical sector planning and shows the strongest concern for the low short-circuit capacity to stall wind-power expansion. This view is also the least concerned with the use of foreign labor in creating problems for new wind farms. Recognition of the high quality of the small number of technical staff in the regulatory agency and the need for decentralized planning in local forums also attest to the importance of organizational issues in "Participating in wind."

The social perspectives analyzed in this paper add to a recent debate on engineering and technical aspects relating to high penetration scenarios of wind power in Brazil $[12,21,33]$ by providing the first empirical evidence that subjective understandings of technical and institutional barriers are not evenly distributed across key actors in the wind-power sector. The social perspectives we analyze have different (but not contradictory) core ideas about engineering and technical barriers to wind-power penetration. Resolving these different barriers would require varied policy interventions by decision makers. Notably, one social perspective ("Participating in wind") includes references and suggestions to issues of energy planning.

We also corroborate the importance in Brazil of the large spinning reserve and capacity for wind forecasting as potential obstacles, as other groups have reported [15,35]. The tensions among the social perspectives we describe here also have broad parallel to the challenges reported recently regarding possible negative outcomes in a federal system that lacks coordinated policy and planning among national and state governments [36]. Finally, respondents were not concerned by issues relating to opposition by host communities previously reported [24,34], probably because these complaints have remained localized, failing to reach the organizational centers where the respondents work, or because respondents believe that local managers are resolving concerns.

\section{Conclusions}

The four observed social perspectives and supporting arguments present a different understanding of how stakeholders understand barriers and challenges. "Failing because of the grid," "Environmental challenges," and "Planning for wind" include barriers reported in Brazil [15] and globally for renewable power penetration, stressing particular concerns rooted in respondents' setting in Brazilian institutions. But "Participating in wind" presents novel views of the need to develop wind power on solid technical, environmental, and economic grounds, rather than prioritizing a particular technical issue. Indeed, "Participating in wind" reveals the contradictions between an ideology of participatory democracy embodied in Brazilian energy planning institutions post-dictatorship, and the reality of exclusionary 
practices. This social perspective is a dissonant discourse with relation to centralized discourses about renewable power, notably including entrepreneurs and wind turbine manufacturers, who demand improvements in regard to ways of participating in decision-making regarding wind power.

Our paper focused on specific aspects of regulators and wind power developers, while also suggesting that the hydropower system has created some unintentional challenges for wind power dissemination. Empowering regional forums, to which "Participating in wind" referred, to inform national electricity planning will help improve penetration in Northeastern Brazil by enhancing institutional participation. The findings support concerns raised by other scholars that sociopolitical relations at municipal scales may override federal governance processes [36]. The social perspectives, overall, suggest the need to understand overlaps between federal-state coordination challenges for energy planning and more narrowly defined technical challenges of the electricity sector. The findings also indicate the need for the state to invest in necessary infrastructure for renewable power, including a network of anemometers capable of supporting changes in the power market and research on solutions to the spinning reserve problem. In terms of research design, this study shows the ability of Q-method to be applied in highly technical sectors and to offer results that may be translated to social scientists with interests in energy policy and planning.

Author Contributions: Conceptualization, C.A.F. and C.B.; methodology, C.A.F. and C.B.; formal analysis, C.A.F. and C.B.; investigation, C.A.F.; writing-original draft preparation, C.A.F.; writing-review and editing, C.A.F. and C.B.; project administration, C.A.F.; funding acquisition, C.A.F. and C.B.

Funding: This research was funded by the National Council for Scientific and Technological Development (CNPq-PDJ 405098/2017-0) and the Comissão de Apoio a Pessoal de Nível Superior (CSF-PVE-S88887.116401/2016-0) within the project “Impactos da Energia Eólica no Litoral do Nordeste: perspectivas para a construção de uma visão integrada da produção de energia 'limpa' no Brasil" (CAPES-PVE88881.068108/2014-01).

Conflicts of Interest: The authors declare no conflict of interest. 


\section{Appendix A}

Table A1. Z-scores and rank of each statement by factor. Bold indicates significance at $p<0.05$; * identifies significance at $p<0.01$. Non-significant "consensus" statements are indicated by underline.

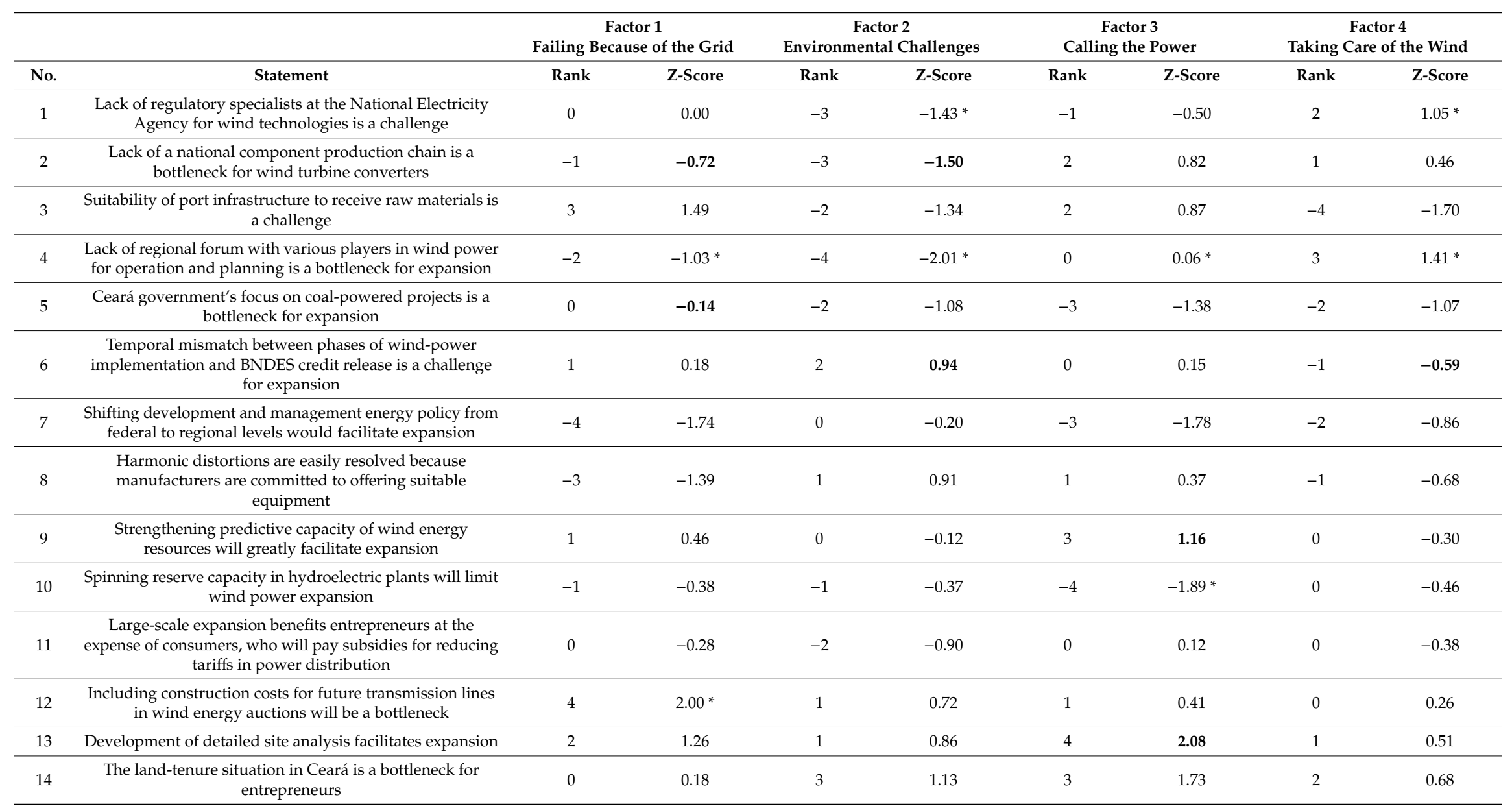


Table A1. Cont.

\begin{tabular}{|c|c|c|c|c|c|c|c|c|c|}
\hline \multirow[b]{2}{*}{ No. } & \multirow[b]{2}{*}{ Statement } & \multicolumn{2}{|c|}{$\begin{array}{c}\text { Factor } 1 \\
\text { Failing Because of the Grid }\end{array}$} & \multicolumn{2}{|c|}{$\begin{array}{c}\text { Factor } 2 \\
\text { Environmental Challenges }\end{array}$} & \multicolumn{2}{|c|}{$\begin{array}{c}\text { Factor } 3 \\
\text { Calling the Power }\end{array}$} & \multicolumn{2}{|c|}{$\begin{array}{l}\text { Factor } 4 \\
\text { Taking Care of the Wind }\end{array}$} \\
\hline & & Rank & Z-Score & Rank & Z-Score & Rank & Z-Score & Rank & Z-Score \\
\hline 15 & $\begin{array}{l}\text { Use of labor among foreign firms for installation, } \\
\text { operation, and maintenance creates onerous dependency }\end{array}$ & -1 & -0.44 & 0 & 0.07 & 0 & -0.07 & -3 & $-1.39 *$ \\
\hline 16 & $\begin{array}{l}\text { Transformation of mental model of technical staff in the } \\
\text { power sector is a challenge because it originated in } \\
\text { hydro-thermal generation }\end{array}$ & 0 & -0.02 & 2 & $0.97^{*}$ & -1 & -0.53 & 0 & -0.04 \\
\hline 17 & $\begin{array}{l}\text { Adjusting turbines to local conditions of temperature, } \\
\text { salinity, humidity, and sand is a facilitator }\end{array}$ & 1 & $\underline{0.31}$ & 2 & $\underline{1.00}$ & 1 & $\underline{0.60}$ & 2 & $\underline{1.18}$ \\
\hline 19 & $\begin{array}{l}\text { Short-circuit capacity of the national electric system must } \\
\text { be solved for large-scale expansion }\end{array}$ & 3 & $1.30^{*}$ & 0 & -0.18 & -2 & -0.73 & 4 & $2.54^{*}$ \\
\hline 20 & Wind farms in interior Ceará face interconnection problems & 2 & 1.20 & 0 & 0.34 & -1 & -0.31 & 3 & 1.23 \\
\hline 21 & $\begin{array}{c}\text { Opposition of environmental movements to licensing is a } \\
\text { bottleneck for expansion }\end{array}$ & -2 & $-1.21^{*}$ & 3 & 1.39 & 0 & 0.17 & 1 & 0.64 \\
\hline 22 & $\begin{array}{l}\text { Easing of environmental impact reporting facilitates } \\
\text { expansion }\end{array}$ & -2 & $-1.01 *$ & 4 & $1.54^{*}$ & 0 & 0.25 & 1 & 0.55 \\
\hline 23 & $\begin{array}{l}\text { National Operating System already has necessary } \\
\text { resources for operation and dispatch }\end{array}$ & -3 & -1.26 & -1 & -0.60 & 2 & $0.73 *$ & -1 & -0.50 \\
\hline 24 & $\begin{array}{l}\text { Capture of value-added taxes by host municipalities would } \\
\text { improve local benefit distribution }\end{array}$ & 1 & 0.93 & 0 & 0.50 & -2 & $-1.37^{*}$ & 0 & 0.17 \\
\hline 25 & $\begin{array}{l}\text { Criticisms by host communities is a problem for } \\
\text { wind-power expansion }\end{array}$ & 0 & $\underline{0.00}$ & -1 & $\underline{-0.74}$ & -1 & $\underline{-0.70}$ & -2 & $\underline{-0.93}$ \\
\hline 26 & $\begin{array}{l}\text { Expectations of local employment and income generation } \\
\text { cause reduced community acceptance }\end{array}$ & -1 & -0.78 & -1 & -0.64 & -2 & $\underline{-0.96}$ & -1 & $\underline{-0.59}$ \\
\hline
\end{tabular}




\section{References}

1. Reddy, S.; Painuly, J.P. Diffusion of renewable energy technologies: Barriers and stakeholders' perspectives. Renew. Energy 2004, 29, 1431-1447. [CrossRef]

2. Davies, S.W.; Diaz-Rainey, I. The patterns of induced diffusion: Evidence from the international diffusion of wind energy. Technol. Forecast. Soc. Change 2011, 78, 1227-1241. [CrossRef]

3. Sovacool, B.K.; Ratan, P.L. Conceptualizing the acceptance of wind and solar energy. Renew. Sustain. Energy Rev. 2012, 16, 5268-5279. [CrossRef]

4. Sine, W.D.; Lee, B.H. Tilting at Windmills? The environmental movement and the emergence of the U.S. wind energy sector. Adm. Sci. Q. 2009, 54, 123-155. [CrossRef]

5. Pinto, J.T.M.; Amaral, K.J.; Janissek, P.R. Deployment of photovoltaic in Brazil: Scenarios, perspectives and policies for low-income housing. Sol. Energy 2016, 133, 73-84. [CrossRef]

6. Echegaray, F. Understanding stakeholders' views and support for solar energy in Brazil. J. Clean. Prod. 2014, 63, 125-133. [CrossRef]

7. Diniz, A.S.A.C.; Neto, L.V.M.; Camara, C.F.; Morais, P.; Cabral, C.V.; Oliveira Filho, D.; Ravinetti, R.F.; França, E.D.; Cassini, D.A.; Souza, M.E.M.; et al. Review of the photovoltaic energy program in the state of Minas Gerais, Brazil. Renew. Sustain. Energy Rev. 2011, 15, 2696-2706. [CrossRef]

8. Martins, F.R.; Pereira, E.B. Enhancing information for solar and wind energy technology deployment in Brazil. Energy Policy 2011, 39, 4378-4390. [CrossRef]

9. Wolsink, M. Wind power: Basic challenge concerning social acceptance. In Encyclopedia of Sustainability Science and Technology; Meyers, R.A., Ed.; Springer: New York, NY, USA, 2012; Volume 17, pp. 12218-12254.

10. del Río, P.; Unruh, G. Overcoming the lock-out of renewable energy technologies in Spain: The cases of wind and solar electricity. Renew. Sustain. Energy Rev. 2007, 11, 1498-1513. [CrossRef]

11. Empresa de Pesquisa Energética. Plano Decenal de Expansão de Energia 2027; Ministério de Minas e Energia: Brasília, Brazil, 2018.

12. de Jong, P.; Dargaville, R.; Silver, J.; Utembe, S.; Kiperstok, A.; Torres, E.A. Forecasting high proportions of wind energy supplying the Brazilian Northeast electricity grid. Appl. Energy 2017, 195, 538-555. [CrossRef]

13. Juárez, A.A.; Araújo, A.M.; Rohatgi, J.S.; Oliveira Filho, O.D.Q. Development of the wind power in Brazil; Political, social, and technical issues. Renew. Sustain. Energy Rev. 2014, 39, 828-834. [CrossRef]

14. Silva, R.C.; Marchi Neto, I.; Seifert, S.S. Electricity supply security and the future role of renewable energy sources in Brazil. Renew. Sustain. Energy Rev. 2016, 59, 328-341. [CrossRef]

15. Diógenes, J.R.F.; Claro, J.; Rodrigues, J.C. Barriers to onshore wind farm implementation in Brazil. Energy Policy 2019, 128, 253-266. [CrossRef]

16. Amarante, O.A.C.; Brower, M.; Zack, J.; Sá, A.L. Atlas do Potencial Eólico Brasileiro/Atlas of Brazilian Wind Power Potential; Ministério de Minas e Energia: Brasília, Brazil, 2001.

17. Rife, D.L.; Pinto, J.O.; Monaghan, A.J.; Davis, C.A.; Hannan, J.R. Global distribution and characteristics of diurnally varying low-level jets. J. Clim. 2010, 23. [CrossRef]

18. Associação Brasileira de Energia Eólica (ABEEÓLICA). Números Abeeólica Fevereiro de 2019; ABEEÓLICA: São Paulo, Brazil, 2019.

19. de Jong, P.; Sánchez, A.S.; Esquerre, K.; Kalid, R.A.; Torres, E.A. Solar and wind energy production in relation to the electricity load curve and hydroelectricity in the northeast region of Brazil. Renew. Sustain. Energy Rev. 2013, 23, 526-535. [CrossRef]

20. de Jong, P.; Kiperstock, A.; Torres, E.A. Economic and environmental analysis of electricity generation technologies in Brazil. Renew. Sustain. Energy Rev. 2015, 52, 725-739. [CrossRef]

21. Miranda, R.; Soria, R.; Schaeffer, R.; Szklo, A.; Saporta, L. Contributions to the analysis of "Integrating large scale wind power into the electricity grid in the Northeast of Brazil" [Energy 100 (2016) 401-415]. Energy 2017, 118, 1198-1209. [CrossRef]

22. de Jong, P.; Kiperstok, A.; Sánchez, A.S.; Dargaville, R.; Torres, E.A. Integrating large scale wind power into the electricity grid in the Northeast of Brazil. Energy 2016, 100, 401-415. [CrossRef]

23. Brannstrom, C.; Gorayeb, A.; de Souza, W.F.; Leite, N.S.; Chaves, L.O.; Guimarães, R.; Gê, D.R.F. Perspectivas geográficas nas transformações do litoral brasileiro pela energia eólica. Revista Brasileira de Geografia 2018, 63,3-28. [CrossRef] 
24. Brannstrom, C.; Gorayeb, A.; de Sousa Mendes, J.; Loureiro, C.; de Andrade Meireles, A.J.; da Silva, E.V.; de Freitas, A.L.R.; de Oliveira, R.F. Is Brazilian wind power development sustainable? Insights from a review of conflicts in Ceará state. Renew. Sustain. Energy Rev. 2017, 67, 62-71. [CrossRef]

25. Frate, C.A.; Brannstrom, C. Stakeholder subjectivities regarding barriers and drivers to the introduction of utility-scale solar photovoltaic power in Brazil. Energy Policy 2017, 111, 346-352. [CrossRef]

26. Matinga, M.N.; Pinedo-Pascua, I.; Vervaeke, J.; Monforti-Ferrario, F.; Szabó, S. Do African and European energy stakeholders agree on key energy drivers in Africa? Using Q methodology to understand perceptions on energy access debates. Energy Policy 2014, 69, 154-164. [CrossRef]

27. Wolsink, M.; Breukers, S. Contrasting the core beliefs regarding the effective implementation of wind power. An international study of stakeholder perspectives. J. Environ. Plan. Manag. 2010, 53, 535-558. [CrossRef]

28. Chang, R.; Cao, Y.; Lu, Y.; Shabunko, V. Should BIPV technologies be empowered by innovation policy mix to facilitate energy transitions?-Revealing stakeholders' different perspectives using Q methodology. Energy Policy 2019, 129, 307-318. [CrossRef]

29. Ellis, G.; Barry, J.; Robinson, C. Many ways to say 'no', different ways to say 'yes': Applying Q-Methodology to understand public acceptance of wind farm proposals. J. Environ. Plan. Manag. 2007, 50, 517-551. [CrossRef]

30. Schmolck, P. PQMethod Software, Version 2.11; Munich, Germany, 2002.

31. Webler, T.; Danielson, S.; Tuler, S. Using Q Method to Reveal Social Perspectives in Environmental Research; Social and Environmental Research Institute: Greenfield, MA, USA, 2009.

32. Brown, S.R. Political Subjectivity: Applications of Q Methodology in Political Science; Yale University Press: New Haven, CT, USA, 1980.

33. Faria, F.A.M.; Jaramillo, P. The future of power generation in Brazil: An analysis of alternatives to Amazonian hydropower development. Energy Sustain. Develop. 2017, 41, 24-35. [CrossRef]

34. Gorayeb, A.; Brannstrom, C.; Meireles, A.J.A.; Mendes, J.S. Wind power gone bad: Critiquing wind power planning processes in northeastern Brazil. Energy Res. Soc. Sci. 2018, 40, 82-88. [CrossRef]

35. Nimmagadda, S.; Islam, A.; Bayne, S.B.; Walker, R.P.; Caballero, L.G.; Camanes, A.F. A study of recent changes in Southwest Power Pool and Electric Reliability Council of Texas and its Impact on the US wind industry. Renew. Sustain. Energy Rev. 2014, 36, 350-361. [CrossRef]

36. Harvey, N.; Dew, R.E.C.; Hender, S. Rapid land use change by coastal wind farm development: Australian policies, politics and planning. Land Use Policy 2017, 61, 368-378. [CrossRef] 